DOI https://doi.org/10.30525/978-9934-26-047-6-47

\title{
СУЧАСНИЙ ТРЕНД СУСПІЛЬНОЇ ГЕОГРАФІЇ: МІКРОГЕОГРАФІЯ
}

\author{
Покляцький С. А. \\ кандидат географічних наук, стариий науковий співробітник \\ Інституту географії Національної академї наук України \\ м. Київ, Україна, \\ методист II категорії лабораторії \\ експериментальних освітніх методик \\ Національного ичентру «Мала академія наук Украӥни» \\ м. Київ, Украӥна
}

Проблематика вивчення міст в українській суспільно-географічній науці упродовж останніх десятиріч стрімко увірвалася на п'єдестал топових тем дослідження. Цей ажіотаж, безумовно, викликаний низкою причин. У першу чергу це пов'язано зі світовими трендами розвитку нашої науки. «Хвиля урбаністики», яка наприкінці XX століття охопила Північну Америку і Західну Свропу, нарешті дійшла і до нас. 3 іншої сторони, географи-науковці підлаштовуються під запити суспільства, проявляючи маневреність та мобільність в переосмислені об'єктно-предметного поля.

Фактично, кількість опублікованих праць, захищених кандидатських та докторських робіт, реалізованих наукових проектів, тем та грантів, проведених конференцій і навіть відкриття окремих спеціальностей у закладах вищої освіти перетворили урбаністичний напрям в мейнстрим географічної науки. Масштаби проведених робіт беззаперечно вражають, але з іншої сторони цілком логічно постає питання, а що далі?

Для осмислення майбутніх перспектив, напевно, слід зазирнути в історію розвитку суспільної географії незалежної України. Цей період фактично нараховує три десятиліття, які умовно можна розділити на три етапи і кожен з них має своє чітко виражене об'єктне поле.

І етап або так звані 90-і, по суті був відголосом радянської моделі розвитку науки. Ключову увагу суспільні географи приділяли дослідженню «економічних районів», які були актуальними у Радянському Союзі. 3 часом стало зрозуміло, що модель управління «зверху-вниз», тобто від більших територіальних одиниць до менших, підходить або ж для високорозвинених країн, або ж для тих, які мають проблеми 3 
демократією. Україна, як молода держава, досі перебуває в процесі побудови демократичного суспільства, а економічний стан нашої країни бажає бути кращим. Тому, цілком зрозуміло, що актуальність дослідження даної одиниці була під питанням, як тоді, так і наразі, оскільки в адміністративно-територіальному устрої нашої країни «економічні райони» не сформовані до сих пір.

II етап або ж перше десятиліття 2000-х, означився намаганнями визначити вектор розвитку як української науки, так і економіки країни в цілому. У цих пошуках суспільні географи здебільшого переорієнтовувалися на «область» як ключовий об'єкт дослідження. Одиниця, зафіксована лише в думках, а і на папері, мала би дати новий поштовх. Водночас, проблема економічного розвитку країни не була вирішена, а тому і подібні дослідження попри їх реальну актуальність були не затребувані. Цей етап дав чітке розуміння (особливо для старшого покоління науковців) того, що найближчими десятиліттями не варто очікувати замовлень з боку держави.

III етап або ж 2010-2020 pp. - перший період в у новітній українській суспільній географії, коли ми намагалися піти на випередження загальнодержавним процесам у країні. Цьому сприяла низка причин, $є$ зокрема, розуміння економічного стану країни, вектору української науки, а також глибокий аналіз розвитку географії у світі.

По-перше, ми дійшли розуміння, що вирішення більшості проблем у нашій країні відтерміновуються на невизначений період у зв'язку 3 постійними економічними проблемами. У такому випадку питання впровадження реформ «зверху-вниз» апріорі не можливі. Для нашої країни ідеальним $\epsilon$ впровадження реформ на місцях, які б з часом давали позитивний ефект на більші територіальні одиниці.

По-друге, реформування науки, про яке вже серйозно велася мова, вказувало нам на переорієнтацію у бік досліджень, які були б затребувані з боку держави. Питання реальних впроваджень поставало все більш гостро. Це, в свою чергу, безумовно наводило на думку про те, що менший територіальний об'єкт дає більше шансів на практичне втілення результатів.

По-mpeme, технічний прогрес дав змогу суттєво покращити знання з розвитку світової географії. Доступний інтернет, онлайн-перекладачі та в цілому відкриття різноманітних баз даних дозволили ознайомитися 3 актуальними темами дослідження в європейському та північноамериканському просторах.

Відповідно, моментами розуміючи, моментами інтуїтивно, ми зазначили вектор об’єктного поля в суспільній географії - від більших 
територіальних одиниць до менших. По суті, зробивши аналіз, ми фактично оминули дослідження «районів» i відразу ж перейшли до категорії «місто».

Здавалося, що ми нарешті потрапили в «яблучко» і йдемо в ногу 3 тими реформами, які почали відбуватися в Україні. У державі було створено Міністерство розвитку громад та територій, проводиться адміністративно-територіальна реформа, в ході якої продовжується процес утворення об'єднаних територіальних громад, а також розглядається законопроект про агломерації. Власне, акцент на менших територіальних одиницях з боку держави важко не помітити.

Водночас, саме в цей період МОН України нарешті вибудувало «модель» розвитку української науки. Згідно даної моделі наука поступово позбувається державного фінансування і бере курс на комерціалізацію. Постала мова про дослідження, які приносять прибутки і як мінімум дають соціальну значущість [1]. А це в свою чергу відкриває для суспільної географії новий етап досліджень, який для нас моментами не зрозумілий і суперечливий.

Окрім великого багажу теоретико-методологічних напрацювань на третьому етапі географи почали налагоджувати співпрацю 3 певними урядовими і неурядовими організаціями. Ми змогли серйозно перелаштуватися в плані функціональних обов'язків, більшість відкрила для себе світ наукового менеджменту і маркетингу. Проте, нам ще дуже далеко від простої співпраці до реальних проектів 3 управлінськими структурами в контексті практичних застосувань результатів досліджень. Низька ефективність впровадження результатів суспільногеографічних досліджень поряд із конкуренцією 3 боку регіональної економіки не дозволяють представникам суспільної географії гідно конкурувати на ринку наукових вітчизняних i міжнародних проектів [2].

Географи знову перебувають в ситуації коли слід рухатися далі. Хочемо ми того чи ні, але процес перегортання сторінки вже запущений. Аналізуючи попередні дані, ситуацію у світі та в країні загалом, не важко здогадатися, що вектор залишається вірним і незмінним - «від більших територіальних одиниць до менших». Фактично, наразі ми вже говоримо про повноцінний перехід до «мікрогеографії». Цей напрям дозволить: відкрити нові можливості в практичному втіленні результатів; покращити візуальний контакт 3 досліджуваним об'єктом; збагатити методичну основу; підсилити менеджерську та маркетингову функції сучасних науковців. Даний перехід безумовно відкриє перед нами нові перспективи. 


\section{Література:}

1. Руденко Л.Г., Маруняк Є.О., Черваньов I. Г. Географія: актуалізації на тлі світових трендів. Укр. геогр. журн. 2018. № 2. C. $17-25$.

2. М.О. Барановський. Сучасні проблеми розвитку суспільної географії: криза ідей чи власні прорахунки. Географічна наука та освіта: від констатації до конструктивізму: Зб. наук. праць. - К., 2018. - C. $15-17$. 